\title{
KADAR FIBRINOGEN SEBAGAI FAKTOR PROGNOSTIK PASIEN PERDARAHAN INTRASEREBRAL SPONTAN
}

\author{
FIBRINOGEN VALUE AS PROGNOSTIC FACTOR IN SPONTANEOUS \\ INTRACEREBRAL HEMORRHAGE
}

\begin{abstract}
David Tandian, * Muhammad Harisyah, * Hanif Gordang Tobing, * Samsul Ashari, * Renindra Ananda Aman, * Syaiful Ichwan,* Mohamad Saekhu,* Wismaji Sadewo, *Affan Priyambodo, * Setyo Widi Nugroho*
\end{abstract}

\begin{abstract}
Introduction: Spontaneous intracerebral haemorrhage (SIH) refers as spontaneous bleeding in the brain parenchyma due to injury of blood vessels. Thus causing tissue inflammatory and coagulation reaction, activating the release of fibrinogen. Fibrinogen, an active substrate of coagulation cascade, also considered as the most powerful indicator of acute inflammatory response in SIH. Elevated levels of fibrinogen may be the marker for the increasing degree of brain tissue damage.
\end{abstract}

Aims: Determine the correlation of fibrinogen levels with outcomes of patients with SIH who went on operative procedures.

Methods: The study was conducted in Dr. Cipto Mangunkusumo hospital and its affiliation hospitals from January until August 2017. Total sampling was conducted. Preoperative Glasgow Coma Scale (GCS), blood volume, preoperative and postoperative serum fibrinogen values, and modified Rankin Scale (mRS) data were obtained and analyzed using the Spearman correlation test.

Results: Significant correlation were found between the preoperative and postoperative fibrinogen with $m R S$ score. Positive correlation coefficients were shown in both parameters, whereas the increase of preoperative and postoperative fibrinogen would increase the $m R S$ score.

Discussion: Pre and postoperative fibrinogen value showed significant association with mRS score, thereby they could be considered as prognostic predictive factors. However, because of the limited number of subject of this study to fulfill the criteria of validity study, a future study with a larger scale should be carried out.

Keyword: Fibrinogen, $m R S$, outcome, spontaneous intracerebral haemorrhage

\section{ABSTRAK}

Pendahuluan: Perdarahan intraserebral spontan (PISS) adalah perdarahan spontan pada parenkim otak akibat kerusakan pembuluh darah pada jaringan otak. Kerusakan tersebut menimbulkan reaksi inflamasi jaringan dan koagulasi yang mengaktivasi pelepasan fibrinogen. Fibrinogen merupakan substrat aktif kaskade koagulasi yang juga merupakan penanda paling kuat respons akut inflamasi pada PISS. Adanya peningkatan kadar fibrinogen dapat menggambarkan peningkatan derajat kerusakan jaringan otak.

Tujuan: Mengetahui korelasi kadar fibrinogen dengan luaran pasien dengan PISS yang dilakukan tindakan operatif.

Metode: Penelitian dilakukan di RSUPN Dr. Cipto Mangunkusumo dan rumah sakit jejaring pendidikan dalam periode Januari-Agustus 2017. Sampel diambil dengan total sampling, data yang diambil adalah, Glasgow Coma Scale (GCS) preoperasi, volume perdarahan, kadar fibrinogen serum preoperasi dan pascaoperasi, dan modified Rankin Scale (mRS), kemudian dianalisis dengan tes Spearman correlation.

Hasil: Dari uji statistik didapatkan hasil bermakna antara fibrinogen preoperasi mau pun pascaoperasi dengan skor mRS. Koefisien korelasi, menunjukkan korelasi positif pada keduanya, dimana peningkatan fibrinogen preoperasi dan pascaoperasi akan meningkatkan skor mRS.

Diskusi: Fibrinogen pre dan pascaoperasi sebagai faktor prediksi prognostik memiliki hubungan bermakna dengan skor mRS. Namun dengan jumlah sampel penelitian yang masih belum mencukupi untuk memenuhi kriteria validitas untuk dapat diajukan sebagai faktor yang bersifat pasti, diperlukan penelitian lebih lanjut dengan sampel yang lebih besar.

Kata kunci: Fibrinogen, luaran, mRS, perdarahan intraserebral spontan

*Departemen Bedah Saraf FK Universitas Indonesia/RSUPN Dr. Cipto Mangunkusumo, Jakarta. Korespondensi: mharisyah@gmail.com.

\section{PENDAHULUAN}

Perdarahan intraserebral spontan (PISS) adalah perdarahan spontan pada parenkim otak akibat kerusakan pembuluh darah otak. ${ }^{1}$ Patofisiologi perdarahan intraserebral spontan meliputi pecahnya pembuluh darah, pembentukan hematom, dan edema di sekitar hematom. Hematom mencapai volume optimal dalam hitungan menit pasca-munculnya 
gejala. Rangkaian proses tersebut menimbulkan reaksi inflamasi jaringan dan mengaktivasi pelepasan fibrinogen. $^{2}$ Peningkatan tekanan intrakranial merusak keutuhan jaringan lokal serta sawar darah otak, dan terjadi bendungan vena yang menyebabkan pelepasan tromboplastin jaringan dan fibrinogen sebagai bagian dari kaskade koagulasi. ${ }^{3}$

Berdasarkan fungsi dan peran fibrinogen pada patofisiologi PISS tersebut, diketahui bahwa semakin meningkatnya kadar fibrinogen serum menggambarkan peningkatan derajat kerusakan jaringan otak yang terjadi. Studi oleh Castellanos menunjukkan bahwa fibrinogen merupakan penanda paling kuat respons akut inflamasi pada PISS dan sebagai substrat aktif kaskade koagulasi. ${ }^{4}$ Peningkatan kadar fibrinogen sebagai respons terhadap aktivasi molekul yang berperan dalam proses inflamasi jaringan, dapat memberi gambaran kerusakan jaringan lokal di sekitar hematom. ${ }^{5}$

Oleh karena itu dilakukan penelitian ini, dibahas mengenai faktor prediksi prognostik berupa kadar fibrinogen serum sebagai penanda proses inflamasi akut dan kaskade koagulasi pada pasien PISS yang dilakukan tindakan operasi.

\section{TUJUAN}

Mengetahui korelasi antara kadar fibrinogen terhadap luaran pasien dengan PISS yang dilakukan tindakan operasi.

\section{METODE}

Penelitian kohort prospektif terhadap pasien PISS yang dilakukan operasi kraniotomi evakuasi hematom di RSUPN Dr. Cipto Mangunkusumo, Jakarta dan RS pendidikan jejaring Departemen Bedah Saraf Fakultas Kedokteran Universitas Indonesia, Jakarta. Sampel penelitian diambil secara konsekutif pada bulan Januari-Agustus 2017.

Kriteria inklusi adalah pasien dengan perdarahan intraserebral supretentorial spontan yang telah dilakukan kraniotomi evakuasi hematoma dengan usia $\geq 50$ tahun. Adapun kriteria eksklusi adalah pasien perdarahan intraserebral sekunder, terdapat penyakit sistemik kronik (gangguan ginjal, penyakit hepar, keganasan), dan dengan riwayat penggunaan obat-obat antikoagulan.
Tabel 1. Karakteristik Demografi Subjek Penelitian $(\mathrm{n}=\mathbf{2 0})$

\begin{tabular}{|c|c|}
\hline Karakteristik & n (\%) \\
\hline \multicolumn{2}{|l|}{ Jenis kelamin } \\
\hline - Laki-laki & $11(55)$ \\
\hline - Perempuan & $9(45)$ \\
\hline Usia (rerata, min-maks) & $57,5(50-65)$ \\
\hline \multicolumn{2}{|l|}{ Glasgow Coma Scale (GCS) } \\
\hline - 8 & $5(25)$ \\
\hline - 9 & $4(20)$ \\
\hline - 10 & $5(25)$ \\
\hline - 11 & $2(10)$ \\
\hline - 12 & $1(5)$ \\
\hline - 13 & $1(5)$ \\
\hline - 14 & $1(5)$ \\
\hline - 15 & $1(5)$ \\
\hline \multicolumn{2}{|l|}{ Modified Rankin Scale (mRS) } \\
\hline - 1 & $1(5)$ \\
\hline - 2 & $4(20)$ \\
\hline - 3 & $4(20)$ \\
\hline - 4 & $2(10)$ \\
\hline - 5 & $3(15)$ \\
\hline - 6 & $6(30)$ \\
\hline \multicolumn{2}{|l|}{ Kadar fibrinogen preoperasi (mg/dL) } \\
\hline - $<200$ & $3(15)$ \\
\hline - $200-400$ & $11(55)$ \\
\hline - $>400$ & $6(30)$ \\
\hline \multicolumn{2}{|l|}{ Kadar fibrinogen pascaoperasi (mg/dL) } \\
\hline - $<200$ & $2(10)$ \\
\hline - $200-400$ & $5(25)$ \\
\hline - $>400$ & $13(65)$ \\
\hline Volume hematoma (rerata, min-maks) & $45(30-60)$ \\
\hline
\end{tabular}

Diambil data kadar fibrinogen pre dan pascaoperasi, Glasgow Coma Scale (GCS) preoperasi, volume perdarahan (dihitung berdasarkan pengukuran panjang x lebar x tinggi dibagi 2), ${ }^{6}$ dan modified Rankin Scale (mRS) saat pasien dipulangkan (jika pasien meninggal skor $\mathrm{mRS}=6$ ).

Penelitian telah menjalani proses lolos kaji etik oleh Panitia Tetap Etik Penelitian Kedokteran/ Kesehatan FKUI dan RSCM nomor 353/UN2.F1/ ETIK/2017. Data diolah menggunakan korelasi Spearman dan dimasukkan ke program SPSS. 


\section{HASIL}

Didapatkan 20 subjek penelitian dengan proporsi laki-laki hampir sama dengan perempuan (55\% vs $45 \%)$ dan rerata usia 57,5 (50-65) tahun. Median GCS adalah 10 (8-15) dan mRS saat pasien dipulangkan adalah 4 (1-6).

Rerata kadar fibrinogen preoperasi adalah 355,15 (142-650)mg/dL yang meningkat pasca operasi 447,15 (134-672)mg/dL (nilai normal 200$400 \mathrm{mg} / \mathrm{dL}$. Adapun rerata volume perdarahan adalah 45,05 (30-60)mL (Tabel 1).

Tabel 2 menunjukkan hubungan yang bermakna antara fibrinogen preoperasi dan skor $\mathrm{mRS}$ dengan nilai $\mathrm{p}=0,012$. Koefisien korelasi $\mathrm{r}=0,549$, menunjukkan korelasi positif dengan kekuatan tingkat menengah dimana peningkatan fibrinogen preoperasi akan meningkatkan skor mRS, dan sebaliknya.

Analisis hubungan fibrinogen pascaoperasi dan skor mRS saat pasien keluar perawatan rumah sakit, didapatkan hasil bermakna antara fibrinogen preoperasi dan skor mRS dengan nilai $\mathrm{p}=0,031$, didapatkan koefisien korelasi $\mathrm{r}=0,482$, menunjukkan korelasi positif dengan kekuatan tingkat menengah, bahwa peningkatan fibrinogen pascaoperasi akan meningkatkan skor mRS, dan sebaliknya.

Analisis hubungan GCS awal dan skor mRS saat pasien keluar perawatan rumah sakit, didapatkan nilai $\mathrm{p}=0,005$ yang berarti menunjukkan hubungan bermakna. Dengan $\mathrm{r}=-0,602$; menunjukkan korelasi negatif dengan kekuatan tingkat menengah. Semakin rendah GCS preoperasi maka semakin tinggi nilai mRS yang berarti memperburuk luaran.

Analisis hubungan volume perdarahan dan skor mRS saat pasien keluar perawatan rumah sakit, didapatkan nilai $\mathrm{p}$ adalah 0,945 , yang berarti hubungan korelasi antara volume perdarahan dengan skor mRS tidak bermakna.

\section{PEMBAHASAN}

Pada penelitian ini didapatkan 20 subjek dengan proporsi laki-laki hampir sama dengan perempuan $(55 \%$ vs $45 \%)$, seperti hasil Ong dkk. Rerata usia subjek penelitian ini adalah 57,5 (50-65) tahun, lebih muda dari Ong dkk, yaitu $64 \pm 11$ tahun. Demikian pula median GCS preoperasi adalah 10 (8-15), tidak berbeda jauh dengan Ong, yaitu $11 \pm 4$. $^{7}$
Tabel 2. Hubungan Fibrinogen Pre dan Pascaoperasi dengan Modified Rankin Scale (mRS)

\begin{tabular}{lllll}
\hline Variabel & n (\%) & $\begin{array}{l}\text { mRS } \\
(\text { min- } \\
\text { maks) }\end{array}$ & r & p \\
\hline
\end{tabular}

\begin{tabular}{|c|c|c|c|c|}
\hline \multicolumn{5}{|c|}{ Fibrinogen preoperasi } \\
\hline - $<200$ & $3(15)$ & $3(1-3)$ & & \\
\hline - $200-400$ & $11(55)$ & $3(2-6)$ & 0,549 & 0,012 \\
\hline - $>400$ & $6(30)$ & $6(5-6)$ & & \\
\hline
\end{tabular}

Fibrinogen pascaoperasi

\begin{tabular}{lcccc} 
- $<200$ & $2(10)$ & $2(1-3)$ & & \\
- $200-400$ & $5(25)$ & $4(2-5)$ & 0,482 & 0,031 \\
- $>400$ & $13(65)$ & $5(2-6)$ & & \\
GCS preoperasi & & & & \\
- 8 & $5(25)$ & $5(2-6)$ & & \\
- 9 & $4(20)$ & $5(2-6)$ & & \\
- 10 & $5(25)$ & $4(3-6)$ & & \\
- 11 & $2(10)$ & $3(3-4)$ & $-0,602$ & 0,005 \\
- 12 & $1(5)$ & 3 & & \\
- 13 & $1(5)$ & 2 & & \\
- 14 & $1(5)$ & 2 & & \\
- 15 & $1(5)$ & 1 & & \\
Volume perdarahan & & & \\
- 30 & $2(10)$ & $3(1-6)$ & & \\
- 32 & $1(5)$ & 3 & & \\
- 35 & $4(20)$ & $5(3-6)$ & & \\
- 36 & $1(5)$ & 2 & & \\
- 40 & $2(10)$ & $3(2-5)$ & 0,000 & 0,945 \\
- 42 & $1(5)$ & 3 & & \\
- 45 & $1(5)$ & 6 & & \\
- 48 & $1(5)$ & 4 & & \\
- 58 & $1(5)$ & 6 & & \\
- 60 & $6(30)$ & $4(2-6$ & & \\
\hline
\end{tabular}

Nilai rerata mRS saat pasien dipulangkan adalah 4 (1-6) yang berarti bergantung berat dan tidak dapat berjalan tanpa bantuan.

Fibrinogen merupakan penanda respons fase akut terhadap perdarahan intraserebral spontan yang menggambarkan tingkat keparahan proses inflamasi serta besarnya volume jaringan otak yang mengalami kerusakan. Studi yang dilakukan oleh Castellanos, menyatakan bahwa fibrinogen adalah variabel dengan kapasitas prediksi terbesar, dimana kadar fibrinogen normal merupakan prediktor luaran 
yang baik pada pasien PISS yang tidak dilakukan operasi. ${ }^{3}$ Studi lain yang dilakukan Van den Herik, menyebutkan bahwa pasien dengan kadar fibrinogen yang tinggi akan memiliki kemungkinan luaran yang tidak baik. ${ }^{8}$ Dengan tingginya kadar fibrinogen serum yang didapatkan pada pasien dengan PISS, menggambarkan kaskade inflamasi dan koagulasi yang terjadi semakin hebat dengan keterlibatan struktur parenkim otak yang lebih banyak. Pada penelitian ini, didapatkan fibrinogen pre dan pascaoperasi memiliki kemaknaan dengan luaran pascaoperasi berupa skor mRS. Semakin tinggi nilai fibrinogen pre dan pascaoperasi, skor mRS akan semakin tinggi, begitu pula sebaliknya.

Studi oleh Wei Naili pada pasien pascakraniotomi dengan patologi primer tumor intrakranial didapatkan bahwa kadar fibrinogen normal pascaoperasi memberikan luaran yang lebih baik. Didapatkan bahwa kadar fibrinogen normal memberikan stabilitas bekuan darah yang lebih baik. ${ }^{9}$ Kadar fibrinogen diluar interval normalnya menyebabkan koagulopati, perdarahan yang sulit dikendalikan, dan potensi perdarahan berulang. Fibrinogen mengalami peningkatan konsentrasi pascaoperasi disebabkan mekanisme pembentukan sebagai protein fase akut akibat reaksi inflamasi, reaksi lokal jaringan terhadap substrat toksik berupa adanya darah/hematom yang merupakan bagian proses aktivasi mikroglia akibat reaksi inflamasi jaringan. ${ }^{10}$

Semakin tinggi kadar fibrinogen pre dan pascaoperasi cenderung akan memberikan hasil luaran buruk pada pasien PISS yang dilakukan operasi, dan kadar fibrinogen pre dan pascaoperasi yang rendah dalam interval nilai normal cenderung akan memberikan luaran yang lebih baik. Dengan hasil tersebut, kadar fibrinogen pre dan pascaoperasi pada kasus perdarahan intraserebral spontan yang dilakukan operasi pada penelitian ini memiliki potensi untuk menjadi faktor prediksi prognostik. Namun masih didapatkan nilai korelasi menengah, dapat disebabkan karena jumlah sampel yang terbatas dan waktu pemantauan yang masih singkat.

Pada penelitian ini, GCS preoperasi yang rendah akan memberikan luaran yang buruk. Sebaliknya, skor GCS preoperasi yang tinggi akan memberikan luaran yang lebih baik. Chaurisa menyatakan bahwa GCS awal yang buruk adalah prediktor peningkatan mortalitas, ${ }^{11}$ demikian pula Pandey menyatakan bahwa skor GCS yang rendah merupakan prediktor kuat mortalitas. ${ }^{12}$ Didapatkan pada penelitian ini, bahwa skor GCS preoperasi memiliki kecenderungan untuk dapat dijadikan sebagai faktor prediksi prognostik pada pasien perdarahan intra serebral spontan yang menjalani operasi.

Keterbatasan penelitian ini adalah jumlah sampel yang belum memenuhi kriteria untuk menjadikan kadar fibrinogen sebagai faktor prognostik serta tidak dilakukan penilaian mRS awal. Hal ini disebabkan oleh keterbatasan waktu penelitian dan jumlah sampel yang dimiliki oleh peneliti.

\section{KESIMPULAN}

Kadar fibrinogen pre dan pascaoperasi, serta GCS preoperasi memiliki kecenderungan/potensi untuk menjadi faktor prediksi prognostik.

\section{DAFTAR PUSTAKA}

1. Huynh T. Developing and validating prognostic scores for patients with acute intracerebral hemorrhage [tesis]. Toronto: University of Toronto; 2013.

2. Magistris F, Bazak S, Martin J. Intracerebral hemorrhage: pathophysiology, diagnosis and management. MUMJ. 2013;10(1):15-22.

3. Ziai WC. Hematology and inflammatory signaling of intracerebral hemorrhage. Stroke. 2013;44(6 Supl 1):S74-8.

4. Castellanos M. Predictors of good outcome in medium to large spontaneous supretentorial intracerebral haemorrhages. J Neurol Neurosurg Psychiatry. 2005;76(5):691-5.

5. Specogna AV, Turin TC, Patten SB, Hill MD. Factors associated with early deterioration after spontaneous intracerebral hemorrhage: a systematic review and meta-analysis. PLos One. 2014;9(5):e96743.

6. Newman GC. Clarification of abc/2 rule for ICH volume. Stroke. 2007;38(3):862.

7. Ong TZ, Raymond AA. Risk factors for stroke and predictors of one-month mortality. Singapore Med J. 2002;43(10):517-21.

8. Acton QA. Protein precursors advances in research and application. Scholarly Edition. 2013;3:94-5.

9. Wei N, Jia Y, Wang X, Zhang Y, Yuan G, Zhao B, dkk. Risk factors for postoperative fibrinogen deficiency after surgical removal of intracranial tumors. Plos One. 2015;10(12):1-10.

10. Kilicarslan A, Uysal A, Roach EC. Acute phase reactants. Acta Medica. 2013;2:2-7. 
11. Chaurisa AK, Mathur MK, Dwidevi NC, Mishra M. Stroke mortality: predictive valeu of simple laboratory tests and acute physiology, age, chronic helath evaluation III scoring system a hospital based study. Int J Res Med Sci. 2016;4(5):1496-500.
12. Pandey P, Dwivedi N, Yadav R, Sonkar K. Mortality in acute stroke: predictive value of lipid profile and routine investigations. Int J Adv Med. 2015;2(3):23540. 